\title{
Functional Analysis of Small Towns Economic Role in Rural Development, Case Study: Zahedshahr, Iran
}

\author{
Issa Ebrahimzadeh", Najmeh Tayyebi, Yousef Shafei \\ Faculty of Geography and Environmental Planning, University of Sistan and Baluchestan, Zahedan, Iran. \\ Email: ${ }^{*}$ iebrahimzadeh@yahoo.co.uk
}

Received June $20^{\text {th }}, 2012$; revised July $23^{\text {rd }}, 2012$; accepted August $2^{\text {nd }}, 2012$

\begin{abstract}
The growing increase in the number of small towns, brought about as a result of Iran's demographic changes in recent decades, has necessitated due consideration of these towns in the country's hierarchical urban system on the one hand and their economic function in their immediate periphery on the other. In the present article, an analysis has been conducted of the economic role Zahedshahr has played as a small town in its rural periphery by using the Jacqueline Beaujeu Garnier and George Shapou's Model, as well as the Locational Coefficient and the Abscissa-Ordinate Graphic Models. Results obtained from the analysis showed that the above town, in spite of its small size, has played an effective role in providing services to the inhabitants of its surrounding areas, as well as acting as a center for sale of surplus agricultural products, thanks to its relatively equipped administrative, educational, commercial, etc., centers. The findings of this research also showed the development of Zahedshahr to be directly dependent on the social and economic conditions of its periphery, so that rural population and agricultural products stability can influence such development.
\end{abstract}

Keywords: Small Towns; Economic Function; Service Providing; Rural Development; Zahedshahr

\section{Introduction: Definition of the Problem}

Since early times and in all countries and civilizations, urbanism has been the most obvious way of human societies' evolution. However, with the advent of the Industrial Revolution and the ever-increasing expansion of cities, particularly metropolises, human societies have been confronting numerous problems, the most significant of which being the extreme centralization in one (or a few) cities, and the consequent disruption of the hierarchical urban system in most countries [1]. According to research results published by the United Nations, 71 of 114 developing countries deemed as unacceptable the spatial distribution of their population, and have initiated fundamental reforms to bring about substantial changes into not only the spatial distribution, but also the internal displacement of the same. Another 24 countries (amounting to 20 percent of all countries in the world) believed their population distribution to be somewhat unacceptable and in need of intervention or policymaking [2]. This trend still exists, so that in Iran today, the urban network does not have a hierarchical function and the number of dwellings (habitation centers), their spatial distribution, and their population does not correspond to a hierarchical system. Moreover, the urban network con-

\footnotetext{
"Corresponding author.
}

tinues to shift towards decentralization [3]. To address issues such as overcrowded cities and the difficulties associated with them, exorbitant costs of building new cities in Iran (which are not quite successful projects anyway) [4], and the reinforcing of economic cities (which leads to decentralization and increases pressure on large cities), the establishment of small towns should be considered [5]. Such towns not only help the processes of decentralization, all-encompassing development of different regions in the country, and formation of a strong regular rural urban network, but also, through creating non-agricultural job opportunities and provision of required services, play an effective role in decreasing rural emigration to larger cities. In this way, a suitable background would be provided for balanced distribution of populations, facilities, and capital [6]. Moreover, today a new approach has been raised, in the form of urban function in rural development (UFRD) strategy, which concentrates on establishing small towns in functional relationship with their rural peripheries [7]. Paying due attention to the development of small towns shall, to a certain extent, solve moderate problems in large cities, such as insufficient housing, unemployment, traffic congestion, etc. most of which exist because the functional capacity of such cities are generally ignored [8].

As a small town in Fars Province, Zahedshahr, in spite 
of its 20-year urban history and favorable natural, economic, and social characteristics, is exposed to relative deprivation and underdevelopment. It is true that, having been the center of Shibkouh District for about 20 years, the town has somewhat developed in terms of new facilities, commercial activities, transportation, and services, and it is also true that the traditional sections of the town have been transformed and made more adaptable in terms of more modern functions, but the relatively slow rate of rural economy, combined with the general disregard of potential capabilities of the region, has greatly limited the possibility of positive change in Zahedshahr's rural areas. Recognition of agricultural, stockbreeding, and touristic potentials of this town and its rural periphery, as well as presentation of systematic plans for their correct implementation, can improve the present situation of the district. This research attempts, through investigation of the existing difficulties in Shibkouh District and determination of ways to increase Zahedshahr's role in the development of the rural area around it, to recommend strategies for proportional distribution of services and facilities across the surrounding rural area, for the purpose of bringing about positive demographic, social, and economic stability to the region.

\section{Methodology}

The analytic-comparative methodology used in this article is based on bibliographical studies and field investigations. In the former, in addition to theories on regional development, middle towns, and small towns, the global experience of small towns, as well as the role these towns play in rural development of their peripheries, has been investigated, with a general view directed at Iran's small towns and their role on their rural surroundings. In the latter, i.e., field investigations, upon identification of the existing situation in Zahedshahr, basic knowledge was obtained of the way dwellings were scattered throughout their rural areas by using maps of land terrain, coverage, political divisions, and also villages, supplied by Iran Center for Statistics. Then, Beaujeu Garnier, Spatial Coefficient, and Izard Models were employed and the results obtained from them analyzed by using AutoCAD, GIS, and Office computer packages.

\section{Small Towns: Theoretical Views, Concepts, and Characteristics}

Some researchers believe that instead of an optimum size for a town, an optimum urban distribution system should be considered. In this way, different sizes can exist for towns in terms of their position in the town distribution system [9]. The definition of a small town is equally variable. Nevertheless, a small town is generally considered to have a maximum population of 10,000 [10].
Also, there is a strong relationship between the size, the main activity, and the functional diversity of a town. Small towns are principally chosen for the establishment of small industries and agencies, and as such are kept away from the generative effects of large industries. These towns never experience high rates of growth [11]. The main characteristics of small towns are as follows:

- A considerable proportion of their labor force has non-agricultural jobs.

- The administrative role of these towns is relatively minimal and they are generally centers for low-level public services such as health centers and schools.

- Their contribution to regional and national production is relatively small, but they are deemed as important centers for offering goods and services to the residents of their peripheries, as well as for providing access to regional and national transportation networks.

- Via small towns, the rural and agricultural populations can establish the most communications with mass public service centers [12].

The strategy for development of small towns was proposed in the 1970's in parallel with that of middle towns. In fact, since then, due to increasing disillusionment and frustration resulting from the Downward Penetration Mechanism initially put forward by the neoclassic school to promote economic growth, researchers and planners, in an effort to create a more equitable pattern for spatial economics, have turned their attention to small and middle size urban areas [13]. Ever since, the idea that towns, rather than higher levels of urban systems, can help in the development of rural areas, has been emphasized, thus directing the focus of attention to "rural towns" and small towns in the lower region of the hierarchical urban scale.

The initial work in this field was by Johnson (1970) who based his research on The Central Location Theory. Upon examination of the case study performed in India, Johnson argued development of rural towns for filling the gap between large parasitic cities and villages, is an essential condition for commercializing agriculture, and therefore, improving growth in market towns should be listed among the duties of a planner.

Based on the above mentioned theory which is the framework of this argument, towns should be identified in relation with one another, so that appropriate space and functional combinations can be guaranteed in the urban hierarchy. Later, Johnson's idea was somewhat trimmed by Rondinelli under the title "Urban Function in Rural Development" (UFRD). Rondinelli reinterpreted Johnson's advocacy of selecting key rural towns in rural areas to bring about rural development [14]. In fact, the small town strategy takes a "bottom-to-top" approach towards spreading urbanism, in reaction to the dissatisfaction resulting from the previously proposed "top-to- 
bottom" approach in the regional planning for developing countries [13].

In general terms, since the early 1980 's, more attention has been focused on the development of small towns, e.g., during the 1980 International Conference on Population and the Future of Urban Areas held in Rome, the need for development of smaller towns was especially emphasized [15].

Recent experience in developing countries also emphasizes the beneficial role of small towns in promoting rural development as well as integrating rural and urban economies. Such is the case in countries with different social, economic, and political characteristics, where small towns and satellite towns have, through maintaining access to services, facilities, and non-agricultural job opportunities, as well as providing inspiration and encouragement for commercialization of agriculture, have helped to transform rural economy.

Research findings in different regions show that providing sufficient connections between small towns and the peripheral areas influenced by them will enable these centers to articulate dwelling systems across the region, and thus help the integration of such systems into the national economy [16].

Today, in order to obtain a thorough understanding of small towns' characteristics and the problems associated with them, we should recognize policies that would promote their development. Table 1 shows a brief account of the role of small towns in different theories proposed on organization and development of dwellings.

\section{The Role of Small Towns in the Economic Development of Surrounding Rural Areas}

Geographical studies generally concentrate on large cities, but the fact that geographical routes continue to affect matters in smaller towns, calls for researchers' attention. For example, in the past decade, the degradation of local economy in smaller municipalities in Japan has caused serious damage to the economy in larger cities [18]. Smaller towns and the rural areas economically influenced by them are equally active, so there are many different ways for economic communication between them. Because of these connections, small towns can form a crucial part of the economy in rural societies since the potential for economic growth in small towns is produced in their rural periphery. Now, can small towns play an effective role in stimulating economic growth in rural areas if they are located within reasonable distances? Growth of a town definitely necessitates strong internal communication. Nevertheless, the following should be considered in this regard:

- Weak communication adversely affects trade between towns and internal regions.
- Stronger inter-city (town) connections provide families in the entire region with job opportunities.

- Stronger communication between towns and internal regions are effective in coping with external factors.

- Towns force potential factors to bring about more economic growth [19].

In fact, small towns should aggressively attempt to absorb the available capital in the society and use it for development of rural areas. In this respect, the most important local capital in a society would be its ability to plan [20]. Generally, small towns facilitate economic development of their rural periphery in the following fields:

\subsection{Agricultural Development}

Perhaps the most important role of small towns and satellite towns in agricultural development is establishment of the physical structure necessary for the flow of agricultural goods from farms to final markets. Towns and cities are in turn dependent on agricultural products for their growth and survival. In addition, the economy in small towns, as in larger towns, depends on agricultural production activities for creating jobs [16].

Small towns are crucial in sustaining growth for agricultural production, as well as maintaining rural revenues. Firstly, small towns act as centers for collection and marketing of farm produce (the obvious role), and secondly, they distribute the implements required by the agricultural sector (the less obvious role) [21]. Rondinelli believes that small towns and small market towns play a significant role as markets for agricultural products, and as sources foe supplying implements to trade and agricultural job centers. Economic and physical bonds between rural areas and town centers, and between small towns and larger towns in a region, facilitate not only dynamic relations and the possibility of growth and diversity in regional, but also distribution of revenues through agricultural development [5].

\subsection{Industrial Development}

The close links that exist between small towns and rural environments can contribute in the development of rural industries, particularly handicraft and native industries, bring diversity to rural economy, and influence economic bonds between small and larger towns. On the other hand, development of small towns also improves the distribution of industries [22]. In fact, strengthening industrial development in small and middle towns, as well as linking such programs to the surrounding rural areas through encouraging trade and the like, is the best way of transferring the benefits of modern industrialization to villages. Moreover, it could lead to the emergence of an efficient locational organization in developing countries 
Table 1. The role of small towns in theories proposed on organization and development of dwellings (habitations).

\begin{tabular}{|c|c|c|c|c|}
\hline Theory & $\begin{array}{l}\text { Considered } \\
\text { Topic }\end{array}$ & $\begin{array}{l}\text { General Principles \& Main } \\
\text { Characteristics }\end{array}$ & Results Obtained from Theory & $\begin{array}{l}\text { Relationship between the } \\
\text { Theory and Small Towns }\end{array}$ \\
\hline $\begin{array}{l}\text { Central } \\
\text { Location }\end{array}$ & $\begin{array}{l}\text { Third Part of } \\
\text { Economics } \\
\text { (Services) }\end{array}$ & $\begin{array}{l}\text { - Simultaneous analysis of hierarchical } \\
\text { distribution and the spatial patterns } \\
\text { related to it. } \\
\text { - Simple assumptions and their } \\
\text { theoretical applications (the theory } \\
\text { evolves in six stages). } \\
\text { Different hierarchies for dwellings in } \\
\text { the triple principles of Marketing, } \\
\text { Transportation, and Administration. }\end{array}$ & $\begin{array}{l}\text { Observance of a true world order, } \\
\text { i.e., existence of dwellings and } \\
\text { their significance in economic } \\
\text { development } \\
\text { Growth and development shall } \\
\text { not propagate to other areas unless } \\
\text { central, economically classified } \\
\text { locations are established. }\end{array}$ & $\begin{array}{l}\text { Central locations are usually } \\
\text { synonymous with small towns } \\
\text { serving as centers for providing } \\
\text { goods in regional societies. }\end{array}$ \\
\hline U.F.R.D. & $\begin{array}{l}\text { Method of } \\
\text { Deploying } \\
\text { Urban } \\
\text { Services in } \\
\text { Rural } \\
\text { Centers }\end{array}$ & $\begin{array}{l}\text { Through a spatial-regional analysis, a } \\
\text { method is obtained for determination of } \\
\text { dwellings to locate investments more } \\
\text { efficiently. }\end{array}$ & $\begin{array}{l}\text { Access to an integrated hierarchy of } \\
\text { service centers, so that a wide range of } \\
\text { functions can be provided for a great } \\
\text { many persons, without their being } \\
\text { necessarily present at each dwelling } \\
\text { Rural area development is possible } \\
\text { through strengthening small and } \\
\text { middle towns. }\end{array}$ & $\begin{array}{l}\text { Small towns as well as their infra- } \\
\text { structure and generative activities, } \\
\text { both potential and actual, can play a } \\
\text { crucial role in rural development. } \\
\text { Thus, when all rural centers assume } \\
\text { urban functions, small towns (and } \\
\text { their relations with one another and } \\
\text { with rural areas) act as links to rural } \\
\text { areas in regional development pro- } \\
\text { jects. }\end{array}$ \\
\hline $\begin{array}{l}\text { Center } \\
\text { Periphery }\end{array}$ & $\begin{array}{l}\text { Development } \\
\text { Space }\end{array}$ & $\begin{array}{l}\text { Expansions of locational economics in a } \\
\text { country is a process with the following } \\
\text { stages: } \\
\text { Pre-industrial stage with different local } \\
\text { centers without hierarchy. } \\
\text { Beginning of industrialization with the } \\
\text { advent of a strong center having a large } \\
\text { periphery. }\end{array}$ & $\begin{array}{l}\text { Narrowing of the center/periphery gap } \\
\text { and trying to bring about spatial } \\
\text { stability. } \\
\text { Realization of functional goals as well } \\
\text { as equitable planning. } \\
\text { Dispersion of growth potentials } \\
\text { Achievement of a basic hierarchical } \\
\text { urban system. }\end{array}$ & $\begin{array}{l}\text { In the first stage, small towns are } \\
\text { most powerful locally, but play no } \\
\text { role in regional/national } \\
\text { development, and even show } \\
\text { parasitic and reactionary growth. } \\
\text { In the second and third stages, small } \\
\text { towns are weakened and rural areas } \\
\text { go down to their lowest level. } \\
\text { Finally, in the last stage, small } \\
\text { towns regain their position in the } \\
\text { urban hierarchy and consequently, } \\
\text { development spreads to the } \\
\text { peripheries. }\end{array}$ \\
\hline $\begin{array}{l}\text { Rural-Urban } \\
\text { Development }\end{array}$ & $\begin{array}{l}\text { Villages and } \\
\text { Towns as } \\
\text { Representatives } \\
\text { of the Whole } \\
\text { Region }\end{array}$ & $\begin{array}{l}\text { This theory criticizes economic growth, } \\
\text { industrialization, and their limited } \\
\text { realization in only a few large cities, and } \\
\text { consequently puts forth "the growth pole" } \\
\text { and the spatial dimension strategy of } \\
\text { development at three levels: national, } \\
\text { urban, and regional, as well as the } \\
\text { Agro-Politian approach. } \\
\text { A model is proposed for development, } \\
\text { which emphasizes on basic needs and aims } \\
\text { at social rather than economic growth. } \\
\text { In agricultural economics, the focus of } \\
\text { attention is rural development. Rural } \\
\text { planning is decentralized and dependent on } \\
\text { public participation, as well as local } \\
\text { characteristics. }\end{array}$ & $\begin{array}{l}\text { Transformation of rural features } \\
\text { through adaptation of fundamental } \\
\text { elements. } \\
\text { Reduction of social disorganization on } \\
\text { the way towards development } \\
\text { Release of the potential social energy } \\
\text { through enabling masses in the } \\
\text { transition towards development (the } \\
\text { ideal conclusion). } \\
\text { Conversion of agricultural activities } \\
\text { into non-agricultural activities. } \\
\text { Connection of rural towns to the } \\
\text { regional communication network. }\end{array}$ & $\begin{array}{l}\text { This is the third of the regional } \\
\text { development theories, and midway } \\
\text { between rural and urban } \\
\text { development. Small towns are the } \\
\text { best way of realizing this theory. }\end{array}$ \\
\hline
\end{tabular}

Source: [17].

[23].

Today, many researchers believe industrial decentralization from large cities to small towns and rural centers would lead to increased revenues and creation of new earnings in rural areas, prevent environmental pollution due to the nature of rural industries, create logical relations between work and technology through correct selection of the technology used, and, by means of spatial distribution of industries, forma a balanced social organi- zation in rural areas [24]. In general, the following primary goals are enumerated for industrialization of rural areas and establishment of industry in small towns [23]:

- Creating non-agricultural jobs for unemployed and semi-employed villagers in the same rural area;

- Assisting to stop the flow of immigrants to urban centers;

- Strengthening economic bases in rural centers;

- Utilizing fully the available skills in the region; 
- Stimulating local agricultural production;

- Procuring essential implements and consumer goods for farmers and local people.

\subsection{Services (Market Centers)}

From the standpoint of rural economy, towns as centers for trade markets, play an essential role in bringing strength and sustainability, as well as development, to agriculture, setting a basis for various economic activities in the area, and augmenting local revenues. In fact, in terms of marketing for export, farms are among the earliest establishments to earn revenues for rural areas from external economies. In general, and particularly in the Third World countries, small towns play a crucial role in marketing agricultural products of rural areas, as is explained below:

- A town is counted as a center for purchase and redistribution of agricultural products part of which is consumed within the cities and the rest exported to foreign countries.

- Via towns, rural products could be exported to not only the other regional towns, but also the largest cities.

- Low-priced goods suitable for low-income classes are provided in villages.

- Rural-agricultural products would bring about the establishment of large reputable companies and factories in cities, along with the wholesale of foodstuffs [25].

Overall, creating market centers with a suitable hierarchy aimed at development is an element of sustainable development. Small towns play a significant role in the establishment of this hierarchy in that they can fill the gap between villages and large cities, and distribute marketing as well as distribution centers on a local scale [5].

\section{Zahedshahr's Geography and Demographic Changes}

Zahedshahr, situated at $45^{\circ} 28^{\prime}$ north latitude, and $45^{\circ} 53^{\prime}$ east longitude, is the center of Shibkouh District to the southeast of Fasa County. The town is located in a plain between two mountain ranges, and the Fasa-Zahedshahr road passes through it, forming the town's main thoroughfare. The whole Zahedshahr Plain lies more than 1200 meters above sea level [26]. Table 2 lists the demographical statistics pertaining to Fasa County, Shibkouh District, and the Town of Zahedshahr. Figure 1 shows the location of Zahedshahr and Shibkouh as political divisions of Fasa.

The present-day Zahedshahr has evolved around a rural dwelling located at the center of the region, and is referred to as a rural center (point) in a census conducted before 1986. According to the 2006 census on population and housing, the town had a population of 10,293 persons, living in 230 households [28].

Shibkouh District, with an approximate area of 1004 square kilometers, occupies about 24 percent of Fasa County, and lies to the southwest of the Town of Fasa. The special situation of Shibkouh has turned it into the second most important district in the county, so that Zahedshahr rates, after the Town of Fasa, second in the region, providing part of the services required by inhabitants of Shibkouh. The passage through Shibkouh of the main Fasa-Jahrom road has added to the town's importance in the region. The relatively large population of Zahedshahr is indicative of the essential role played by this district in the demographic texture of the county.

The present-day Zahedshahr has evolved around a rural dwelling located at the center of the region, and is referred to as a rural center (point) in a census conducted before 1986. According to the 2006 census on population and housing, the town had a population of 10,293 persons, living in 230 households [28].

Shibkouh District, with an approximate area of 1004 square kilometers, occupies about 24 percent of Fasa County, and lies to the southwest of the Town of Fasa. The special situation of Shibkouh has turned it into the second most important district in the county, so that Zahedshahr rates, after the Town of Fasa, second in the region, providing part of the services required by inhabitants of Shibkouh. The passage through Shibkouh of the

Table 2. Population of Shibkouh district according to the census conducted in 1986, 1996, and 2006.

\begin{tabular}{ccccccc}
\hline \multirow{2}{*}{ Year } & \multicolumn{5}{c}{ Population } \\
\cline { 2 - 6 } & Fasa & Shibkouh & Zahedshahr & Rate of Growth (Fasa) & Rate of Growth (Shibkouh) & Rate of Growth (Zahedshahr) \\
\hline 1986 & 159,105 & 21,161 & 9733 & 1.45 & -1.13 \\
1996 & 183,818 & 18,880 & 10,495 & & -0.26 \\
2006 & 192,946 & 18,393 & 10,293 & 0.4 & -0.19 \\
\hline
\end{tabular}

Source: [27]. 


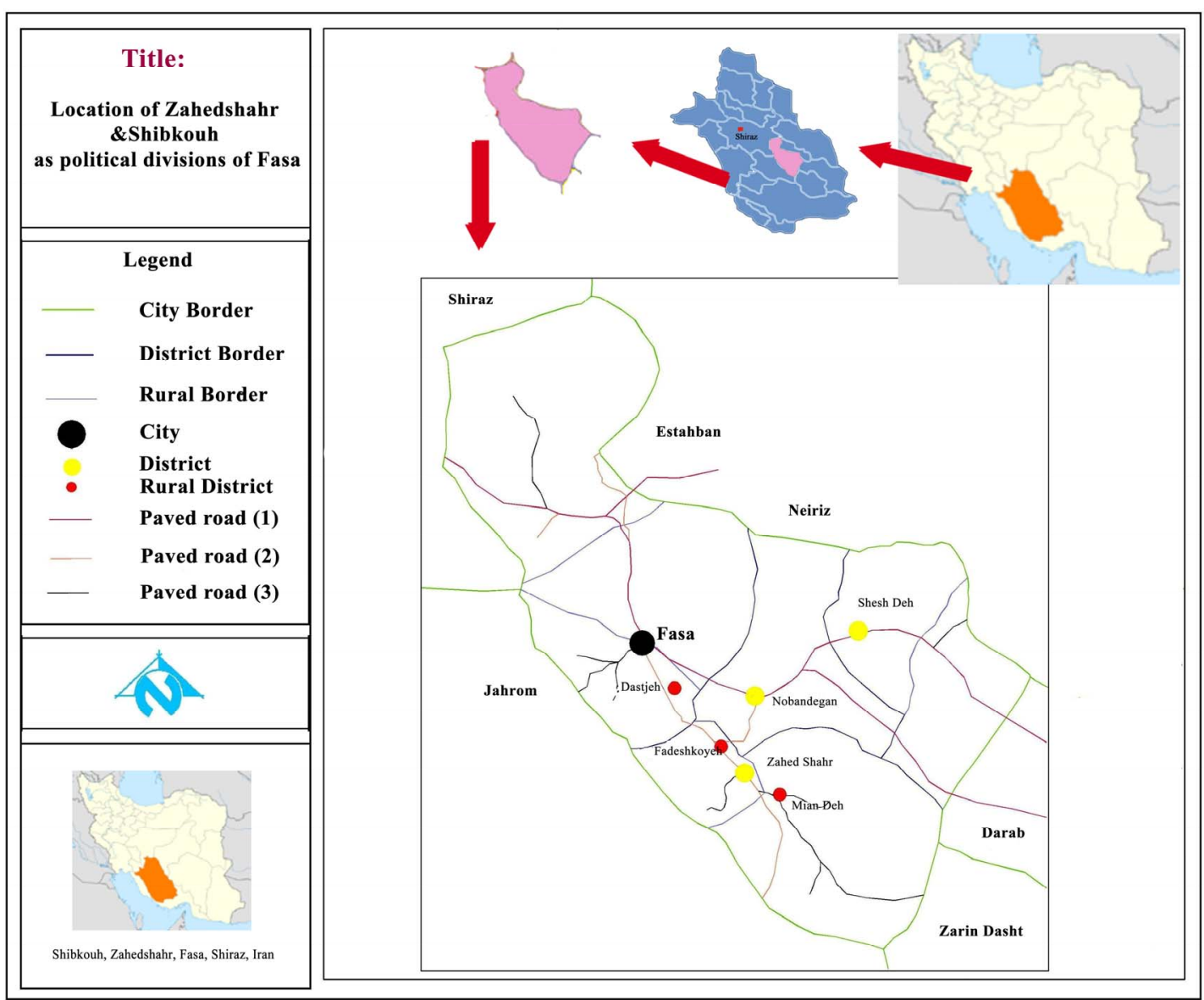

Figure 1. Location of Zahedshahr and Shibkouh as political divisions of Fasa. Source: Designed by authors.

main Fasa-Jahrom road has added to the town's importance in the region. The relatively large population of Zahedshahr is indicative of the essential role played by this district in the demographic texture of the county.

\section{Analysis of Zahedshahr's Economic Indices and Their Effect on the Economy of Its Rural Hinterland}

A fundamental factor in urban and regional planning/ studies is observance of the economic conditions of the region or area that is being studied. Zahedshahr acts as a service-providing center across Shibkouh District which is basically an agricultural region. Studying the town would be incomplete if its economic hinterland is neglected, i.e., the town's role would be far better understood if it is looked at as a part of the whole system with which it interacts.

In this respect, examination of effective economic indices could be highly significant, including employment and unemployment rates, dependency burden, variance of active forces in different industrial, agricultural, and service sectors, as well as indices of income, cost, housing, and property rates. In addition, investigation of financial markets, workshops, and active cooperative companies across the region, as well as operational production units and type of manufactured products, is highly significant. The state of these indices in Zahedshahr and its rural periphery of influence is discussed below. Zahedshahr as center of Shibkouh District, is host to administrative, service, and workshop facilities crucial to the surrounding villages, and as was said before, through its center passes the Fasa-Miandeh-Jahrom road. As a rule, such functions are effective not only in attracting populations from surrounding areas, but also in bringing about development for the county.

Results from Table 3 show that despite a relative reduction in population from 10,495 in 1996 to 10,293 in 2006, the number of employed population has increased by 540 .This is indicative of improved economic situation as well as higher level of investment, and consequently, relative development of the town. This in turn should lead to improved rural functions since the distribution of the employed in Zahedshahr reveals a mainly servicebased economy resulting from the town's acceptance of immigrants. Thus, the total number of employed persons has increased from 2014 in 1996 to 2554 in 2006 [29]. 
Table 3. Active and Employed Population and dependency burden in Zahedshahr in 1996 and 2006.

\begin{tabular}{|c|c|c|c|c|c|c|c|c|c|c|c|}
\hline \multirow{2}{*}{ Year } & \multirow{2}{*}{ Pop. } & \multicolumn{2}{|c|}{ Pop. of Age 10 Years and Older } & \multicolumn{2}{|c|}{ Active Pop. } & \multicolumn{2}{|c|}{ Employed Pop. } & \multicolumn{2}{|c|}{ Unemployed Pop. } & \multirow{2}{*}{$\begin{array}{l}\text { Dependency } \\
\text { Burden (Net) }\end{array}$} & \multirow{2}{*}{$\begin{array}{c}\text { Dependency } \\
\text { Burden (Gross) }\end{array}$} \\
\hline & & No & $\%$ & No & $\%$ & No & $\%$ & No & $\%$ & & \\
\hline 1996 & 10,495 & 7818 & 74.5 & 2451 & 31.4 & 2014 & 82.2 & 437 & 17.8 & 4.2 & 3.3 \\
\hline 2006 & 10,293 & 8816 & 85.65 & 3123 & 34.7 & 2554 & 82 & 569 & 18 & 3 & 2.3 \\
\hline
\end{tabular}

Source: Calculations by the authors based on consensus statistics (1996 \& 2006).

Table 4 shows the maximum level of activity in Zahedshahr in the following fields: trade, transportation, administrative affairs, education, public administration, construction, etc.

On the basis of information given in Table 4, Zahedshahr could be called a strong service-providing center for the entire Shibkouh District since this town acts, on the one hand, as the district's agricultural products market, and on the other hand, as a center for provision of rural services for the district. This fact is of great significance in any future planning, particularly for the determination of the role and function of the town as compared to the range of its functionality.

\section{Application of Economic Models for Functional Analysis of Zahedshahr's Economic Role and Its Periphery of Influence}

\subsection{Beaujeu Garnier and George Shapou Models}

The Beaujeu Garnier Method is used to determine the status quo of employment by major activities in cities, i.e., the percentage of employed persons in agricultural, industrial, and service sectors, as well as the dominant economic function in a city. In the present paper, this model was applied to determine the dominant functional status of Zahedshahr in 1996 and 2006. Results obtained from the analysis show that during the ten-year period, the dominant economic function of the town has been service-providing activities, and that in the same period, there has been a tendency, through introduction of major reforms, towards service/multifunctional activities. In other words, in 1996, the main economic function in $\mathrm{Za}-$ hedshahr was commercial, with a tendency towards providing services, whereas by 2006 , the dominant function had changed completely into providing services. Therefore, it can be concluded that during the 1996-2006 period, Zahedshahr acted as a center for the purchase of surplus agricultural and livestock products, as well as for selling services required by farmers and stockbreeders. The pyramid below depicts the town's dominant economic functions.

Thus, without taking measures in the form of appropriate policies and systematic planning aimed at chang- ing the town's employment structure, Zahedshahr will soon turn into a service-providing consumer town. In this regard, measures such as transforming the town's industrial structure through introduction of agro-industrial or industrial-stockbreeding projects may be considered. Also, the suitable climate, good farmland, and potential human resources (available from local tribes and inhabitants of the surrounding rural areas) would make it possible to activate the agriculture, take up the employment as well as production level, and export the production surplus to other countries or provinces. In this way, the dominant economic function of the town could be maintained within commercial/multifunctional boundaries. Moreover, through correct planning, the town should be able to not only provide the necessary supplies for its citizens, but also earn more revenues for them by exporting the surplus products. All this would result in qualitative and quantitative betterment of lifestyle in the town.

\subsection{Locational Coefficient or Basic Economics Method}

Application of the above model to Zahedshahr reveals different situations in different periods. The locational coefficient calculated for Zahedshahr in 1996 is equal to unity for different sectors. This shows the town's economy is basic (self-sufficient) and in a better condition compared with the higher levels. However, in 2006, the value for the town's locational coefficient is found to be lower in agriculture and industry, and higher in the service sector, which is indicative of growth in this sector. Results obtained from calculations, presented in Table 5, also confirm the fact that in 2006, the locational coefficient for Zahedshahr shows a lower percentage for industry as compared with the reference level. In agriculture and service sectors, however, the above coefficient indicates more self-sufficiency, i.e., more favorable conditions. The following formula was used for calculations of Locational Coefficient $(L Q)$ method:

$$
L Q=E_{L i} / E_{R i}
$$

where, $E_{L i}$ and $E_{R i}$ indicate employment of each economic sector in small town (Zahedshahr), and region respectively.

The results obtained from Basic Economics Model 
Table 4. Type of activity/occupation in different economic fields in Zahedshahr.

\begin{tabular}{|c|c|c|c|c|c|c|c|c|}
\hline \multirow{2}{*}{ Year } & \multicolumn{2}{|c|}{ Agriculture } & \multicolumn{2}{|c|}{ Industry } & \multicolumn{2}{|c|}{ Services } & \multicolumn{2}{|c|}{ Total } \\
\hline & No & $\%$ & No & $\%$ & No & $\%$ & No & $\%$ \\
\hline 2006 & 261 & 10.20 & 154 & 6.0 & 2140 & 83.75 & 2554 & 100 \\
\hline
\end{tabular}

Source: Calculations by the authors based on information supplied by Iran Center for Statistics, 2009.

Table 5. Results obtained from the locational coefficient (LQ) method applied to determine the basic economic situation in Zahedshahr.

\begin{tabular}{|c|c|c|c|c|c|c|c|c|}
\hline \multicolumn{6}{|c|}{ Percentage Share of Each Sector from Total Employment } & \multicolumn{3}{|c|}{ Zahedshahr's LQ Compared with Reference Levels } \\
\hline Year & Economic Sector & Zahedshahr & Fasa County & Fars Province & Iran as a Whole & Fasa County & Fars Province & Iran as a Whole \\
\hline \multirow{3}{*}{1996} & Industry & 30.14 & 28.42 & 28.80 & 31.30 & 1.060 & 1.046 & 0.96 \\
\hline & Services & 42.20 & 42.41 & 47.50 & 45.10 & 0.995 & 0.889 & 0.94 \\
\hline & Total & 100 & 100 & 100 & 100 & - & - & - \\
\hline \multirow{3}{*}{2006} & Agriculture & 10.18 & 29.17 & 23.60 & 23.60 & 0.348 & 0.403 & 0.431 \\
\hline & Industry & 6.5 & 28.42 & 31.30 & 31.30 & 0.228 & 0.228 & 0.207 \\
\hline & Services & 83.32 & 42.41 & 45.10 & 45.10 & 1.964 & 1.799 & 1.847 \\
\hline
\end{tabular}

Source: Calculations by the authors based on information supplied by Iran Center for Statistics, 2009.

analysis are:

For 1996:

- The agricultural sector is "basic" compared with both the province and Iran as a whole;

- The service sector is non-basic compared with the county, province, and Iran as a whole;

- The industry sector is non-basic compared with Iran as a whole, and basic compared with the province and Fasa County.

For 2006:

- The service sector is basic compared with both the province and Iran as a whole;

- Agriculture in Zahedshahr is non-basic compared with the county, the province, and Iran as a whole;

- The industry is non-basic compared with Fasa County, the province, and Iran as a whole [29].

\subsection{Analysis of Zahedshahr's Functional Role on the Basis of Izard's Abscissa-Ordinate Descriptive Model}

This model presents a method for analysis of economic situation for the purpose of understanding and prediction of a town's economic share as compared to the national level. The method is used to calculate growth rates for different economic sectors on a general as well as national basis by taking into account the results obtained from two census counting. Overall, this model discusses the difference in growth between a region's various economic sectors and compares them to the corresponding rates of growth on a national scale. A positive difference obtained for an activity would mean that other similar activities should be transferred "to" the region, and, likewise, a negative difference would indicate that activity is to be transferred "from" the region [30]. Based on this model, in 1996 and 2006, the economies of Fars Province and Zahedshahr were designated as "reference" and "local", respectively. Table 6 shows the 1996 and 2006 quantitative changes obtained from this model for the economic sectors in Fars Province and Zahedshahr. The coefficient of variance in this model is calculated from the relation:

$$
\begin{aligned}
& \text { Coefficient of variance } \\
& =(\text { Ratio for } 2006 / \text { Ratio for } 1996) \times 100
\end{aligned}
$$

Figure 2 shows the situation in economic sectors of Fars Province and Zahedshahr during the 1996-2006 periods, obtained by applying Izard's Model.

Analysis of this diagram reveals the following results:

- The slope of the line being approximately equal to unity (corresponding to a $43^{\circ}$ with the horizontal axis) indicates that the rate of growth for employed people in Zahedshahr is similar to that at the national level 


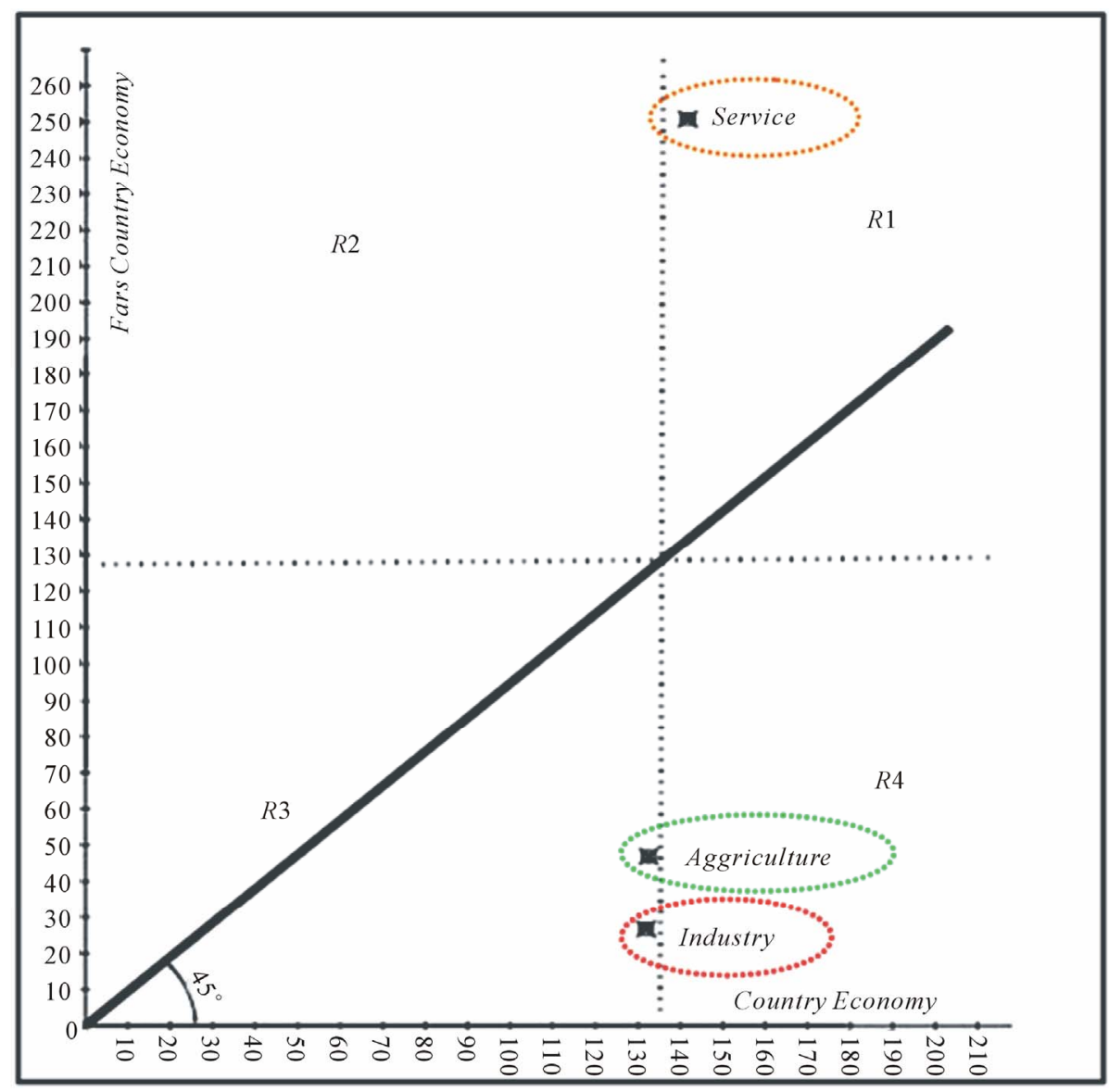

Figure 2. The situation in economic sectors of Fars Province and Zahedshahr during the 1996-2006 by applying Izard's Model. Source: Calculations by the authors, 2009.

Table 6. Comparison of quantitative changes in economic sectors of Fars Province and Zahedshahr (between 1996 and 2006 ).

\begin{tabular}{ccccccc}
\hline Sector & $\begin{array}{c}\text { Fars Province } \\
(1996)\end{array}$ & $\begin{array}{c}\text { Fars Province } \\
(2006)\end{array}$ & $\begin{array}{c}\text { Ratio } \\
(2006 / 1996)\end{array}$ & $\begin{array}{c}\text { Zahedshahr } \\
(1996)\end{array}$ & $\begin{array}{c}\text { Zahedshahr } \\
(2006)\end{array}$ & $\begin{array}{c}\text { Ratio } \\
(2006 / 1996)\end{array}$ \\
\hline Agriculture & 211482 & 280190 & 132.49 & 557 & 260 & 46.68 \\
Industry & 255875 & 337820 & 132.02 & 607 & 166 & 27.34 \\
Services & 409168 & 577590 & 141.16 & 850 & 2128 & 250.35 \\
Total & 876525 & 876525 & 136.40 & 2014 & 2554 & 126.81 \\
\hline
\end{tabular}

Source: Calculations by the authors based on information supplied by Iran Center for Statistics, 2009.

during the mentioned period.

- Position of the service sector in Region 1 shows the rate of growth for employment in this sector in $\mathrm{Za}$ hedshahr exceeds that for industry, and that at the national level, more people are employed in this sector than in other sectors.

Region 3 of the diagram shows a slower rate of growth for employment in the agriculture and industry in $\mathrm{Za}$ hedshahr than that in the service sector. In addition, there is a reduction in the employment rate in the said sectors compared to the mean national employment rate of growth in the service sector.

\subsection{Conclusions and Strategies}

\section{1) Conclusions}

An essential role envisaged for small towns is the development and mobilization of rural economy as well as the agricultural sector. The structure and physical/ economic texture of small towns facilitate the transfer of agricultural products from farms to final markets in rural areas. In addition, through sending expert workforce, innovation, and technology to these areas, small towns can prepare the ground for economic, social, and finally rural development. 
Although the subject of the present research is investigation and analysis of Zahedshahr's economic role in the development of its rural periphery, the range of this role, as was said in the definition of the problem, goes far beyond economy alone. Nevertheless, this paper set out to answer the question "Has Zahedshahr, as a small town, been able to perform its economic role in terms of distribution of goods and services to its surrounding rural areas?" To investigate this point, the existing strategies and certain techniques, as well as models that could be applied to small towns within their regional boundaries, were considered. Then the models applicable to the district were selected, and consequently analyzed. The following general approaches can be proposed upon analysis of the obtained results: Application of Beaujeu Garnier Model to investigate briefly the status and dominant function of Zahedshahr in 1996 and 2006, reveals that during the ten-year period, the town's dominant role has shifted towards providing services. The reason is that once the town was chosen as center of the district, it also became a center for concentration of service-providing facilities. At the same time, during the 1996-2000 decade, the locational coefficient of the town, compared to its levels of reference (i.e., Fasa County, Fars Province, and Iran as a whole), shows a low percentage for the agricultural and industrial sectors, but a relatively more selfsufficient and favorable situation in the service sector. This means the service sector in the town is, compared with reference levels, "basic", while the agricultural and industrial sectors are "non-basic".

In addition, results obtained from analysis of Zahedshahr based on Izard Model, show the growth rate for employed persons to be in conformity with that at the national economy level during the 1996-2006 decade. The position of the service sector in Region 1 of this model indicates a growth in service sector employment in comparison to the industry and agricultural sectors, which is a favorable situation. Also, the agriculture and industry lie in Region 3 of the diagram. This is equivalent to a lower rate of employment in these sectors than in the service sector as well as the national and regional levels.

Finally, examination the results obtained from analysis of overall findings shows that Zahedshahr has relatively desirable administrative, educational, and commercial service centers. Moreover, the town is well known in the region as a center for selling surplus agricultural products, as well as offering services to the people in its rural periphery, as most of the residents in Shibkouh receive their required services from Zahedshahr. Therefore, the overall conclusion is that Zahedshahr has performed a satisfactory role in the distribution of economic function across the rural areas influenced by it.

\section{2) Future Strategies and Proposals}

Without measured policies and systematic planning for changing the employment structure in Zahedshahr, the town is bound to turn into a service-providing consumer center. One such policy could be transformation of the town's industrial structure by introducing agro-industrial or industrial-stockbreeding projects. In addition, the suitable climate, the farmland, and the potential work force available from regional tribes and rural inhabitants, would make it possible to lead the town towards assuming a commercial or multi-functional role through developing agriculture, increasing the number of employed persons, taking up the level of production, and exporting surplus products to other parts of the province or country.

Transportation and communication reflect the state of the infrastructure for development in a region. That is why preparations must be made in this regard to connect the surrounding villages to towns via both roads and qualitatively acceptable communication systems. Only upon being equipped with an efficient communication network can Zahedshahr be transformed into a central market for rural products as well as a center for promotion of rural economy in the surrounding areas.

Small towns, i.e., large villages turned into towns during the past decade, are mainly faced with shortage of logistical services. Existence of such services in small towns for production purposes can be an incentive for the employees in the agricultural sector to increase production and prevent perishable products from being spoiled when market is glutted.

If Zahedshahr is to assume its role for development and equipment of rural and agricultural activities, developed centers such as product-processing installations, storage and packing facilities, as well as distribution means to send products to other regions across the country should be established. This would make essential planning for such functions absolutely necessary.

As agricultural activities are dominant in the rural dwellings around small rural towns, Zahedshahr could play an important role for its rural periphery if, in addition to presenting non-agricultural goods, it hosts local markets and exchange centers for surplus agricultural products. This would strengthen the agriculture sector and positively affect non-agricultural activities: On the one hand, it would bring about an increase in people's purchasing power and consequently an increase in demand for buying non-agricultural products in the town by farmers and the rural community, and on the other hand, create more profound relations between the town and its rural periphery.

Today, the young population in small towns and the surrounding rural areas mostly demand welfare, cultural, and sports services. As, due to insufficiency of allocated funds for such purposes, these services remain unattain- 
able even years after the small town has been recognized as such, it would be necessary to take serious measures to build recreational, cultural, and athletic infrastructure to bring about (young) population stability and cause the development of young people's numerous talents in these towns.

\section{REFERENCES}

[1] A. K. Hahs and M. J. McDonnell, "Selecting Independent Measure to Quantity Melbourne Urban-Rural Gradient," Landscape and Urban Planning Journal, Vol. 78, No. 28, 2006, pp. 435-448.

[2] G. Avijit and A. Rafi, "Geomorphology and the Urban Tropics: Building an Interface between Research and Usage," Geomorphology, Vol. 31, No. 1-4, 1999, pp. 133149. doi: 10.1016/S0169-555X(99)00076-8

[3] A. Nazarian, "Small Towns Role in Spatial Organization and National Development in Zanjan Province," Geographical Research, Vol. 3, 1996, pp. 48-71.

[4] M. H. Saraei and M. Askndy Sani, "Into Large Villages to Small Towns and Their Role of Regional Equilibrium, Case Study: Ryvash, City of Kashmar," Journal of Geography and Development, Vol. 10, 2007, p. 166.

[5] H. Izadi, "Development of Villages into Towns and Its Effect on Rural Development: Case Study in Fars Province," Ph.D. Thesis, Teacher Training University, Tehran, 2001, p. 147.

[6] A. Ruknal-Din Eftekhari and H. Izadi, "A Role in Increasing Rural-Urban Employment Opportunities and Reduce Unemployment in Rural Areas (the Province)," The Second Biennial Conference of Iran, Tehran, 25-28 May 2002, p. 53.

[7] M. Sarrafi, "Foundations, Regional Development Planning," 2nd Edition, Plan and Budget Organization, Tehran, 2000, p. 130.

[8] A. Jokar, "The Role of Small Towns in Rural Development: Case Study: Firouzabad, Fars Province," Master's Thesis, Teacher Training University, Tehran, 2007, p. 3.

[9] S. Abedindarkoush, "Introduction to Urban Economy," 2nd Edition, Nashr-e-Daneshgahi Publications, Tehran, 1993, p. 83.

[10] F. Sefeddini, "Dictionary of Regional and District Planning," Shiraz University Publications, Shiraz, 1999, p. 422.

[11] M. R. Alibabai, "Investigation of the Role Played by Small Towns in Spatial Stability of Population in Sistan and Baluchestan Province," Master's Thesis, Sistan and Baluchestan University, Zahedan, 2002, p. 10.

[12] E. Zebardast, "Size of a City," Iran Center for Architecture and City Planning, Tehran, 2004, p. 36.

[13] L. Omoja, "The Role of Small Towns in Rural Development in Bornostats Nigeria," London University, London, 1987, p. 336.
[14] M. Douglass, “A Regional Network Strategy for Regional Reciprocal Rural-Urban Linkages: An Agenda for Policy Research with Reference to Indonesia," Third World Planning Review, Vol. 20, No. 1, 1998, p. 5.

[15] M. Jafarzadeh Rastin, "Population and Urbanization," Iran Center for Statistics, Tehran, 1987, p. 26.

[16] D. A. Rondinelli, "Towns and Small Cities in Development Countries," The Geographical Review, Vol. 73, No. 4, 1983, pp. 379-395. doi:10.2307/214328

[17] B. Naderi, "Sustainable Development of Small Towns, Case Study: Ghaemieh, Fars," Master's Thesis, Tehran University, Tehran, 2008, p. 84.

[18] M. Yamshita, "Decline and Approaches to Revitalization in Small Cities, the Case of Saga, Japan," University of Ljubljana, Ljubljana, 2004, pp. 461-473.

[19] T. Scottish, "Economic Linkages between Small Towns and Surrounding Rural Areas in Scotland," University of Gloucestershire, Cheltenham, 2005, p. 10.

[20] D. Harris and D. Tanaka, "Tool for Small Towns, Center for Governmental Services," Auburn University, Auburn, 2005, p. 2.

[21] H. Evans and A. Emrys, "A Virtuous Circle Model of Rural-Urban Development: Evidence from a Kenyan Small Towns and Its Hinterland," Journal of Development Studies, Vol. 28, No. 4, 1992, pp. 640-667. doi: $10.1080 / 00220389208422250$

[22] Y. Deyin and Z. Sun, "The Strategic Objective of Urban Development in China: Taking Vigorous Action to Develop Small Cities," In: O. P. Mathur, Ed., Small Cities and National Development, United Nations Centre for Regional Development, Nagoya, 1982, pp. 25-26.

[23] B. Shapuori, et al., "Guidelines for Rural Planning," Journal of Village and Development, Vol. 23, 1996, p. 59.

[24] M. Nozari, "Investigation of Small Towns Formation in Rural Environments: Case Study: Town of Beiza, Fars Province," Master's Thesis, Shiraz University, Shiraz, 2007, p. 43.

[25] H. Shokouei, "New Horizons in Urban Geography," SAMT Publications, Tehran, 2006, p. 296.

[26] http://www.googlemap.com

[27] Fars Province Center for Statistics, "Statistics on Population and Housing," Fars Province Center for Statistics, Shiraz, 2010.

[28] General Population and Housing Census, "Statistical Center of Iran," General Population and Housing Census, Tehran, 2006.

[29] N. Tayyebi, "Small Towns Role in Rural Development: Case Study: Zahedshahr, Fasa," Master's Thesis in Geography and Urban Planning, Sistan and Baluchestan University, Zahedan, 2009, p. 109.

[30] H. Hekmatnia and M. N. Mousavi, "Application of Models in Geography with Emphasis on Regional and Urban Planning," Elm-e Novin Publications, Yazd, 2006, pp. 6465 . 